\title{
Effects of ultraviolet light emitting diodes (LEDs) on microbial and enzyme inactivation of apple juice
}

\author{
Merve Pelvan Akgün, Sevcan Ünlütürk* \\ Department of Food Engineering, Izmir Institute of Technology, Urla, Izmir 35437, Turkey
}

\section{A R T I C L E I N F O}

\section{Keywords:}

Cloudy apple juice

Ultraviolet light-emitting diodes (UV-LED)

E. coli $\mathrm{K} 12$

Bacterial inactivation

Coupled wavelength

Polyphenoloxidase

Enzyme inactivation

\begin{abstract}
A B S T R A C T
In this study, the effects of Ultraviolet light-emitting diodes (UV-LEDs) on the inactivation of E. coli K12 (ATCC 25253), an indicator organism of E. coli O157:H7, and polyphneoloxidase (PPO) in cloudy apple juice (CAJ) were investigated. The clear (AJ) and cloudy apple juice were exposed to UV rays for 40 min by using a UV device composed of four UV-LEDs with peak emissions at 254 and $280 \mathrm{~nm}$ and coupled emissions as follows: 254/365, 254/405, 280/365, 280/405 and 254/280/365/405 nm. UV-LEDs at $254 \mathrm{~nm}$ achieved $1.6 \pm 0.1$ $\log _{10} \mathrm{CFU} / \mathrm{mL}$ inactivation of $E$. coli $\mathrm{K} 12$ at UV dose of $707.2 \mathrm{~mJ} / \mathrm{cm}^{2}$. The highest inactivation of $E$. coli $\mathrm{K} 12$ $\left(2.0 \pm 0.1 \log _{10} \mathrm{CFU} / \mathrm{mL}\right.$ and $\left.2.0 \pm 0.4 \log _{10} \mathrm{CFU} / \mathrm{mL}\right)$ was achieved when the cloudy apple juice was treated with both $280 \mathrm{~nm}$ and 280/365 nm UV-LEDs. For clear apple juice the highest inactivation $4.4 \log _{10} \mathrm{CFU} / \mathrm{mL}$ obtained for $E$. coli K12 was achieved using 4 lamps emitting light at $280 \mathrm{~nm}$ for 40 min exposure time. For the same treatment time, the experiments using a combination of lamps emitting light at 280 and $365 \mathrm{~nm}$ (2lamp/ 2lamp) were resulted in $3.9 \pm 0.2 \log _{10} \mathrm{CFU} / \mathrm{mL}$ reductions. UV-A and UV-C rays in combination showed a better inactivation effect on PPO than UV-C rays used separately. Residual activity of PPO in CAJ was reduced to $32.58 \%$ when treated with UV-LED in combination of UV-C $(280 \mathrm{~nm})$ and UV-A $(365 \mathrm{~nm})$ rays. Additionally, the total color change $(\Delta \mathrm{E})$ of CAJ subjected to combined UV-LED irradiation at 280/365 nm was the lowest compared to other studied processing conditions. This study provides key implications for the future application of UV-LEDs to fruit juice pasteurization.
\end{abstract}

\section{Introduction}

As an alternative to consumption of fruits, drinking fruit juices is easy to consume especially for very young, elderly and infirm people. It is known that consumption of fruit juices decreases the risk of chronic diseases, retards Alzheimer disease onset, slows down LDL oxidation, inhibits platelet aggregation, and prevents the development and progression of coronary artery diseases due to their antioxidant compounds (Borenstein et al., 2005; Keevil et al., 2000; Stein et al., 1999).

Fruit juices are also susceptible to microbial spoilage though they have acidic $\mathrm{pH}$ values. Observation of outbreaks caused by the consumption of unpasteurized fruit juices raised a question about the safety of acidic juices. The most common microorganisms found in fruit juices are acid-tolerant bacteria, yeasts and molds. However, Salmonella and Escherichia coli 0157:H7 outbreaks indicated the potential of fruit juices to carry pathogenic microorganisms (Cook et al., 1998). Foley et al. (2002) estimated the number of cases of illnesses associated with unpasteurized juices as 16,000 to 48,000 in a year.

Thermal pasteurization is the best known technique in order to remove pathogens, reduce the number of spoilage microorganisms and inactivate the enzymes which decrease the quality of the products. However, use of high temperatures may cause some quality problems such as color, taste and flavor defects (Aguilar-Rosas et al., 2007; Choi and Nielsen, 2004).

Increased trend towards fresh-like products forced the researchers to investigate alternative processing techniques (Basaran-Akgul et al., 2009; Tahiri et al., 2006). One of the alternative method to thermal pasteurization is UV-C radiation. Antimicrobial effect of UV-C light is very well known and this technique is used for disinfection of fruits surfaces, hospital equipment, water resources etc. (Begum et al., 2009; Bintsis et al., 2000; Nigro et al., 1998; Pan et al., 2004). Inactivation mechanism of UV-C irradiation is based on the absorption of UV photons by the genetic material and the formation of dimers which inhibit the transcription and replication of the cell (Bolton and Linden, 2003; Koutchma, 2009; Oguma et al., 2002).

On the other hand, many microorganisms are able to repair damages on their DNA caused by UV-C irradiation by means of two different mechanisms depending on the light availability such as

\footnotetext{
* Corresponding author

E-mail address: sevcanunluturk@iyte.edu.tr (S. Ünlütürk)
} 
photoreactivation and dark-repair (Chevremont et al., 2012a; Oguma et al., 2002).

Generally low or medium pressure mercury vapor lamps are used for UV-C irradiation, first one emitting predominantly monochromatic UV irradiation at $254 \mathrm{~nm}$ and second one emitting polychromatic UV irradiation in the wavelengths range from 200 to $400 \mathrm{~nm}$. However, these lamps contain mercury which is known to have toxic effect for both environment and human body (Mori et al., 2007). Additionally, UV reactors are required to be designed according to the shape of the lamps. These lamps are mostly large in size and take up too much space (Chevremont et al., 2012a). Moreover, UV lamps are not resistant to shock and have a low life span (approximately 4000-10,000 h). Therefore, it is necessary to design new disinfection equipment in various sizes which do not contain toxic substances and have low energy consumption rate (Crawford et al., 2005; Hamamoto et al., 2007).

In that regard, the UV disinfection using LEDs (Light Emitting Diode) seems a promising technology. UV-LEDs are created by connecting p-type and n-type semiconductors that move electrons into positively charged holes between these two materials. Light is generated when the electrons and holes recombine at a junction. The wavelength of light depends on the type of material that is used for those semiconductors (i.e. indium gallium nitride for light in the visible range, and aluminum gallium nitride and aluminum nitride for $\mathrm{UV}$ range) (Bowker et al., 2011). They have a very compact, shock-resistant and robust design. They can also be used for disinfection of narrow spaces and allow saving space due to their small sizes. UV-LEDs do not need a warm-up time in contrast to traditional UV-C lamps. Hence, they consume less energy. It was also reported that UV-LEDs have relatively longer life time exceeding 100,000 h (Chevremont et al., 2012a). Most importantly, they do not contain any toxic substances which are harmful for human health and the environment. They are capable of emitting UV light at multiple individual wavelengths. Besides, it is possible to use the combination of different UV-LEDs emitting light at different wavelengths.

UV-LEDs emitting light in food industry are used for three main areas such as food production, postharvest storage and food safety (D'Souza et al., 2015). A serious number of studies have published showing the efficiency of LEDs on postharvest applications succeeded in delaying of senescence in vegetables (Braidot et al., 2014; Ma et al., 2014), accelerating secondary metabolites during ripening process (Xu et al., 2014a; Xu et al., 2014b) and increase or delaying loss of postharvest nutritional content of plant parts, including edible flowers and fruits such as broccoli, citrus and strawberries (Dhakal and Baek, 2014; Ma et al., 2014; Shi et al., 2014).

There are limited numbers of studies related to the use of UV-LEDs for water disinfection. Chatterley and Linden (2010) reported that most of those data were available for LEDs emitting light at UV-A range. However, UV-C LEDs were also indicated to be preferred for this purpose (Bowker et al., 2011; Chevremont et al., 2012a; Chevremont et al., 2012b; Hamamoto et al., 2007; Li et al., 2010; Würtele et al., 2011). Moreover, combination of UV-A and UV-C LEDs was used in some studies (Aoyagi et al., 2011; Chevremont et al., 2012a). Bowker et al. (2011) indicated that emitted UV light at $275 \mathrm{~nm}$ resulted in much higher microbial inactivation. This is due to the fact that protein absorption spectrum reaches the maximum near $280 \mathrm{~nm}$ and thus, enzymes become more sensitive to inactivation at these wavelengths. Moreover, at a wavelength range of 200 to $280 \mathrm{~nm}$ (UVC) and 280 to $315 \mathrm{~nm}$ (UV-B), it has a damaging effect on DNA replication and transcription. Direct exposure to UVC or UV-B results in dipyrimidine dimers, pyrimidine hydrates, or cross-links between proteins and DNA. Hence, it is capable of inactivating a variety of pathogens such as bacteria, viruses, fungi, protozoa, and other pathogenic organisms (Lui et al., 2014). Furthermore, it is known that UV-A radiation mechanism is based on the inactivation of microorganisms by damaging proteins and producing hydroxyl and oxygen radicals which destroy cell membrane and other cellular components (Chevremont et al., 2012a).
Although DNA damage caused by UV-C radiation can be repaired by the enzyme photolyase, there is no possibility to repair the damage to bacterial membranes by UV-A radiation. Chevremont et al. (2012a) showed that coupling UV-A and UV-C could be paired by using the germicidal effect of UV-C and greater penetrating ability of UV-A. They also found that use of coupled wavelengths $280 / 365 \mathrm{~nm}$ and 280 / $405 \mathrm{~nm}$ caused total disappearance of fecal enterococci, total coliforms and fecal coliforms in the effluent. Besides lack of possibility to repair the damage in the bacterial membranes occurred after UV-A exposure increased the efficiency of microbial inactivation (Chevremont et al., 2012a).

Moreover, inactivation of the quality degrading enzymes which depends on the intensity of the radiation is successfully achieved after exposure to light emitted in the range of $250-740 \mathrm{~nm}$ (Falguera et al., 2012). However, there is no study in the literature related to the assessment of the effect of UV-LEDs on the inactivation of microorganisms and enzymes, and quality of the fruit juices.

Therefore, the objective of this study is to investigate the applicability of UV LEDs for the non-thermal treatment of clear (AJ) and cloudy apple juice (CAJ) for the inactivation of microorganisms and quality degrading enzymes without affecting the juice quality. For this purpose, a UV-LED device was constructed for static tests and two different UV-C LED wavelengths $(254 \mathrm{~nm}, 280 \mathrm{~nm})$ were tested independently. UV-LEDs emitting lights in the UV-A range $(365 \mathrm{~nm})$ and a LED array (405 nm) were also coupled as follows: 254/365, 254/405, $280 / 365,280 / 405$ and 254/280/365/405 $\mathrm{nm}$. The microbial effectiveness of UV light treatment was tested by inoculating $E$. coli K12 into AJ and CAJ. Moreover, the effect of UV-LED irradiations on the activity of polyphenol oxidase (PPO) enzyme in CAJ was investigated.

\section{Materials and methods}

\subsection{Apple juice}

Commercial pasteurized clear apple juice (AJ) (Dimes, Kemalpaşa, IZMIR) was purchased from a local market in Izmir, Turkey. AJ does not contain any citric acid and other preservatives. Background flora of pasteurized samples was tested by surface plating on Plate Count Agar (PCA, Sigma-Aldrich, St. Lous, MO, USA) for enumeration of total aerobic bacteria and Violet Red Bile Agar (VRBA, Merck, Darmstadt, Germany) to determine the number of coliforms prior to UV treatment.

For the production of fresh CAJ, apples of the Starking Delicious variety were purchased from a local supermarket (Tesco-Kipa) in Izmir, Turkey. Apples were washed under tap water and patted dry and squeezed using a household table top juice extractor (Arçelik Robolio, İstanbul). After the extraction step, the juice was strained through a sterile gauze strip to remove the big particles and foams in the juice.

\subsection{Physicochemical and optical properties}

The total soluble solids (TSS) and $\mathrm{pH}$ of fresh CAJ and AJ were measured using a bench top refractometer (Mettler-Toledo RE40D, AEA Investors Inc., USA) and a benchtop $\mathrm{pH}$ meter (HANNA Instruments, USA). The titratable acidity of samples was determined according to the method of AOAC (1990) and expressed as the weight of malic acid in $100 \mathrm{~mL}(\mathrm{w} / \mathrm{v})$.

Turbidity was determined using a turbidimeter (Model 2100AN IS, HACH Company, USA) and expressed in Nephelometric Turbidity Units (NTU). Absorbance coefficients of the juice samples were determined using a $1 \mathrm{~cm}$ quartz cuvette in a Cary 100 UV-Visible Spectrophotometer (Varian, USA) adjusted to 254 and $280 \mathrm{~nm}$. A variety of dilution factors were applied $(1: 10,1: 25,1: 50,1: 100,1: 250$, 1:500). The absorption coefficient $\left(\mathrm{cm}^{-1}\right)$ at each individual wavelength was estimated by the slope of absorbance versus sample concentration plot (Hakgüder, 2009).

The color parameters were determined by means of a Konica 
Minolta CR 400 Chromometer (Konica Inc., Japan). CIE L* (brightness-darkness), a* (redness-greenness), b* (yellowness-blueness) were determined before and after UV-LED and thermal treatments. Total color differences $(\Delta \mathrm{E})$ were calculated by the following Eq. (1).

$\Delta E=\sqrt{\left(\Delta L^{*}\right)^{2}+\left(\Delta a^{*}\right)^{2}+\left(\Delta b^{*}\right)^{2}}$

\subsection{Ascorbic acid assay}

Boehringer enzymatic method proposed by Danielczuk et al. (2004) was used for ascorbic acid determination of CAJ samples. For this purpose, test kits (R-Biopharm, Roche, Germany, catalog no. 10409677035) were utilized. In this method, the absorbance of MTTformazan, which is produced by the reaction of reducing substances and tetrazolium salt MTT (3-(4,5-dimethylthiazolyl-2)-2,5- diphenyltetrazolium bromide) in presence of electron carrier PMS (5-methylphenazinium methosulfate) at $\mathrm{pH} 3.5$, is measured at $578 \mathrm{~nm}$. The absorbance difference between the sample and sample blank, of which ascorbic acid is removed by the enzyme ascorbic acid oxidase, yield the quantity of ascorbic acid in the sample (mg L-ascorbic acid/1 sample solution).

\subsection{Microbial inactivation studies}

\subsubsection{UV-LED device}

Static UV-LED unit was designed by considering the similar systems used in the study of Chevremont et al. (2012b). Four UV-LEDs ( $8.33 \mathrm{~mm}$ diameter) (manufactured by SETI Sensor Electronic Technology Inc., Columbia, SC, USA) emitting light at 254, 280, 365 and $405 \mathrm{~nm}$ were used throughout experiments. These LEDs could be used together or separately and the electronic circuit was connected to a customized four channel power supply. Each UV-LED was operated with a constant forward current of $20 \mathrm{~mA}$.

The forward voltage of each UV-LED at $20 \mathrm{~mA}$ was 6.50, 5.8, 5.50 and $3.80 \mathrm{~V}$ for the $254,280,365$ and $405 \mathrm{~nm}$ UV-LEDs, respectively. The optical output power of each UV-LED was $0.20,0.60,0.40$ and $10 \mathrm{~mW}$ for the 254, 280, 365 and $405 \mathrm{~nm}$ UV-LEDs, respectively.

A scheme of the experimental device is shown in Fig. 1. The UVLEDs were fixed facedown, $1 \mathrm{~cm}$ above the surface of a sample $(3 \mathrm{~mL})$ placed in a sterilized Petri dish $(55 \mathrm{~mm}$ diameter). The sample depth was $0.15 \mathrm{~cm}$. The depth was calculated from the ratio of the sample volume and the surface area of a Petri dish. A scheme of the experimental device is shown in Fig. 1. An adequate stirring was applied during treatment in order to ensure equal distribution of UV dose through the sample. The edge effects caused by stirring are avoided by using the smallest possible sample volume (Bolton and Linden, 2003). $\mathrm{UV}$ exposure was performed at room temperature $\left(25^{\circ} \mathrm{C}\right)$.

\subsubsection{UV dose calculation}

UV dose was calculated from the product of incident intensity and exposure time. Incident UV intensity (irradiance) emitted by each LED (in $\mathrm{mW} / \mathrm{cm}^{2}$ ) was measured by ferrioxalate actinometry (Bohrerova et al., 2008; Chevremont et al., 2012b; Edelahi, 2004; Goldstein and Rabani, 2008; Kuhn et al., 2004;). For actinometric determination, potassium ferrioxalate is chosen as a chemical actinometer since it is used in wavelength ranges changing from UV to visible regions (Jankowski et al., 1999). After exposure of a ferrioxalate solution to UV light, the $\mathrm{Fe}^{2+}$ generated were measured by a spectrophotometer (Shimadzu Co. Ltd., Japan) in which the $\mathrm{Fe}^{2+}$ is completed with ophenanthroline $\left(\varepsilon\right.$ complex, $\left.510 \mathrm{~nm}=11,100 \mathrm{M}^{-1} \mathrm{~cm}^{-1}\right)$. The number of $\mathrm{Fe}^{2+}$ ions is used to calculate the incident photon flux (photons.s ${ }^{-1}$ ). The incident photon flux is used to calculate the power emitted by each LED expressed in Watts. Dividing this result by the irradiated surface may allow one to determine the irradiance (or incident UV intensity in $\mathrm{mW} / \mathrm{cm}^{2}$ ) (Chevremont et al., 2012b).

\subsubsection{Bacterial strain and sample inoculation}

In this study, E. coli K12 (ATCC 25253), an indicator organism of $E$. coli O157:H7, was selected as a pertinent pathogen and inoculated into AJ and CAJ samples, respectively. Koutchma et al. (2004) found that UV sensitivities of E.coli O157:H7 and an indicator organism E.coli K12 (ATCC 25253) were not significantly different from each other. The $E$. coli K12 (ATCC 25253) strain was cultured from $-80^{\circ} \mathrm{C}$ lyophilized vials, enriched in a test tube containing nutrient broth (NB, Merck, Darmstadt, Germany) and incubated overnight (18-24 h) at $37^{\circ} \mathrm{C}$. The E. coli K12 (ATCC 25253) culture was first adapted to $\mathrm{pH} 4.0$ by growing in a solution containing malic acid following the procedure described by Pala and Toklucu (2013). Stock cultures were prepared by transferring acid-adapted cells onto TSA slants and stored at $4{ }^{\circ} \mathrm{C}$ until used.

Initially, CAJ samples $(500 \mathrm{~mL})$ were pasteurized by means of a continuous flow pasteurizer to eliminate any background microflora prior to UV-LED treatment. Details of the thermal pasteurization process are given in the Section 2.4.4. A loopful of acid-adapted culture from the TSA slant was first inoculated into $10 \mathrm{~mL}$ of TSB (TSB, Merck, Darmstadt, Germany) for enrichment, and then $1 \mu \mathrm{L}$ from this culture medium was inoculated into $3 \mathrm{~mL}$ of $\mathrm{CAJ}$ and AJ to obtain a final microbial concentration of $6-7 \log _{10} \mathrm{CFU} / \mathrm{mL}$.

\subsubsection{Determination of thermal pasteurization parameters}

Freshly squeezed apple juice was first pasteurized to eliminate the natural background microflora. For this purpose, juice sample was inoculated with $100 \mu \mathrm{l}$ of $E$. coli $\mathrm{K} 12$ cells at a level of approximately $7 \log _{10} \mathrm{CFU} / \mathrm{mL}$ and then subjected to thermal treatment. Heat treatments were carried out by means of a continuous flow pasteurizer (Fig. 2) at different temperatures $\left(70,80,90^{\circ} \mathrm{C}\right)$ and different heating times $(3,10,15,20,30,45,60,120,180 \mathrm{~s})$ to achieve $5 \log _{10} \mathrm{CFU} / \mathrm{mL}$ reduction on $E$. coli $\mathrm{K} 12$. After inoculation, $0.1 \mathrm{~mL}$ samples were collected at different heating times and immediately surface plated on tryptic soy agar (TSA, Merck, Darmstadt, Germany) medium containing $0.1 \%$ dihydrostreptomycin. The pasteurization temperature and time required for $5 \log _{10}$ reduction of $E$. coli K12 in CAJ were calculated.

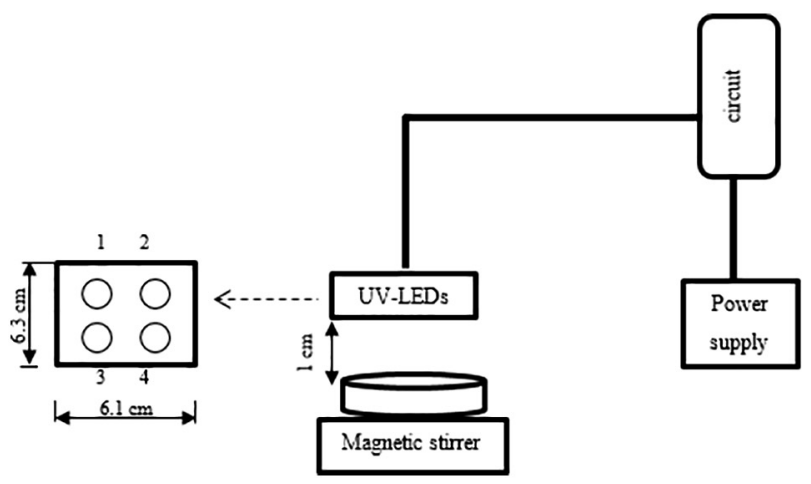

$254 \mathrm{~nm}(1,2,3,4)$
$280 \mathrm{~nm}(1,2,3,4)$
$254 \mathrm{~nm}(1,2) \times 365 \mathrm{~nm}(3,4)$
$254 \mathrm{~nm}(1,2) \times 410 \mathrm{~nm}(3,4)$
$280 \mathrm{~nm}(1,2) \times 365 \mathrm{~nm}(3,4)$
$280 \mathrm{~nm}(1,2) \times 410 \mathrm{~nm}(3,4)$
$254 \mathrm{~nm}(1) \times 280 \mathrm{~nm}(2) \times 365 \mathrm{~nm}(3) \times$
$410 \mathrm{~nm}(4)$

Fig. 1. Static UV-LED system. 


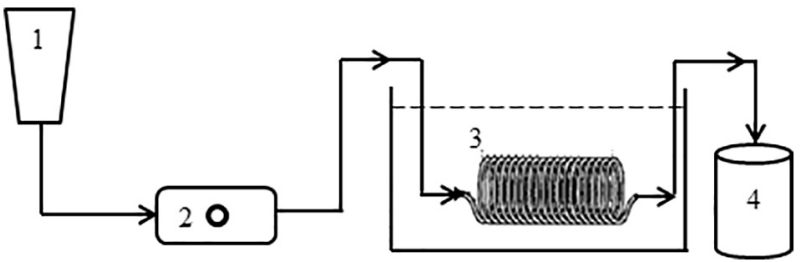

Fig. 2. Schematic diagram of thermal pasteurization system (1: stirrer; 2: peristaltic pump; 3: heating coil; 4: cooler).

\subsubsection{Bacterial enumeration}

Enumeration of the viable microorganisms in the UV-LED treated samples, appropriate dilutions were made with $0.1 \%$ peptone water and surface plated in duplicate on tryptic soy agar (TSA, Merck, Darmstadt, Germany) plates, medium containing $0.1 \%$ dihydrostreptomycin. All of the plates were incubated at $37^{\circ} \mathrm{C}$ for $24 \mathrm{~h}$ and then counted. The freshly squeezed sample was used as a negative control, while a heat treated sample was used as a positive control in this study. Background flora (total aerobic bacteria (TAC), total coliform (TC), yeast and mold counts (YMC)) of the juice samples was checked by pour plating in plate count agar (PCA, Sigma-Aldrich, St. Lous, MO, USA), surface plating on violet red bile agar (VRBA, Merck, Darmstadt, Germany) and potato dextrose agar (PDA, Difco Laboratories, Detroit, Mich) acidified to pH 3.5 with $10 \%$ tartaric acid (Merck, Darmstadt, Germany), respectively. The PCA and VRBA plates were incubated at $37^{\circ} \mathrm{C}$ for $24 \mathrm{~h}$, whereas the PDA plates were incubated at $25^{\circ} \mathrm{C}$ for $2-5$ days.

\subsubsection{Experimental design for determination of UV-LED process conditions}

Different parameters potentially influence the UV inactivation of $E$. coli K12 in CAJ and AJ. The studied factors were the individual wavelengths and the wavelength combinations including 254, 280, 254/ $365,254 / 405,280 / 365,280 / 405$ and $254 / 280 / 365 / 405 \mathrm{~nm}$; and the exposure time, i.e., 20 and $40 \mathrm{~min}$. The temperatures of the samples during UV-LED processing were also monitored by using an infrared thermometer (IR-82, CEM, Shenzhen, China) attached to a Data Logger (DT 8891E, CEM, Shenzhen, China) (Fig. 4). Pairs of UV-LED lamps were connected in parallel to the DC power source as depicted in Fig. 1 (Bowker et al., 2011). The medium depth was fixed at $0.153 \mathrm{~cm}$. Tandon et al. (2003) indicated that the suitable stirring was required to be applied for uniform light distribution. Besides, Bolton and Linden (2003) reported that stirring caused the changing of sample depth from middle to border of petri dish and it affected the absorption of UV light, conversely. Unluturk et al. (2010) proposed the use of minimum amount of sample and showed that the depth at $0.153 \mathrm{~cm}$ of sample provided a homogeneous light distribution.

Pasteurized CAJ and AJ inoculated with E. coli K12 were used as treatment medium for assessment of the microbial efficiency of UVLEDs. All the experiments were replicated twice. Totally 28 runs were performed.

The results were analyzed by using the statistical software StateEase Design Expert Software 7.1 Trial version (Stat-Ease, Inc., Minneapolis, MN, USA).

\subsection{Inactivation of PPO enzyme}

The freshly squeezed CAJ samples were centrifuged at $10000 \mathrm{rpm}$ for $15 \mathrm{~min}$ at $4{ }^{\circ} \mathrm{C}$ (Universal $320 \mathrm{R}$, Hettich, Germany) and the supernatant was collected to test PPO activity. Activity of PPO was assayed by a spectrophotometric method (Bi et al., 2013) with some modifications. The method is based on the measurement of the absorbance of brown polymers formed when catechol is oxidized in presence of polyphenoloxidase at $410 \mathrm{~nm}$. Catechol was used as the substrate, and $0.05 \mathrm{M}$ catechol substrate solution was prepared with $0.2 \mathrm{M}$ phosphate buffer ( $\mathrm{pH} 6.5$ ). All samples were analyzed by adding $0.5 \mathrm{~mL}$ centrifuged juice into $2.5 \mathrm{~mL}$ substrate solution. The increase in absorbance at $410 \mathrm{~nm}$ in $10 \mathrm{~min}$ was immediately monitored after incubation for 3 min using a UV-1800 spectrophotometer (SHIMADZU Co. Ltd., Japan), which was equipped with a peltier thermo-statted cell holder, a water pump (Varian Co. Ltd., California, USA) to keep temperature at $30{ }^{\circ} \mathrm{C}$. An enzyme activity unit was defined as an increase of 0.1 in absorbance per minute. All the experiments were repeated three times. Residual activity of PPO was calculated the following equation:

$\mathrm{RA}, \%=\frac{A_{1} x 100}{A_{0}}$

$A_{1}$ is the enzymatic activity after UV-LED and thermal pasteurization treatment, $A_{0}$ is the enzymatic activity of untreated sample (freshly squeezed). Untreated and pasteurized CAJ samples were used as negative and positive controls.

\section{Results and discussion}

\subsection{Physical, chemical and optical properties of CAJ and AJ}

Some physical and chemical properties of fresh CAJ and AJ samples including $\mathrm{pH}$, total soluble solid (Brix ${ }^{\circ}$ ), titratable acidity, ascorbic acid content, color, absorption coefficient were determined only before the UV-LED treatments depicted in Table 1.

$\mathrm{pH}$ and total soluble solid content of freshly squeezed CAJ extracted from Starking Delicious variety of apples and AJ were 3.92; 3.99 and $13.63^{\circ} ; 13.42^{\circ}$ Brix. These values showed similarity with previous studies. Murakami et al. (2006) were studied 15 different apple varieties. They observed that the $\mathrm{pH}$ and the brix values of apple juice were in between 3.2 and 6.50; 9.80 and $16.90^{\circ}$ Brix. Falguera et al. (2011) were reported that $\mathrm{pH}$ and Brix values of Golden, Starking, Fuji and King David variety of apples were in the range of 3.48 and 4.35; 10.70 and $14.70^{\circ}$ Brix. Ascorbic acid content of apple juice was determined to be $2.22 \mathrm{mg} / \mathrm{L}$ and it was completely diminished after thermal and UV-LED processing due to oxidation arisen from longer exposure time. The ascorbic acid content of fresh apple juice obtained from Starking variety was found lower than the findings of Juarez-Enriquez et al. (2014) and Falguera et al. (2011). The main reason of this might be the usage of different methods for determination of ascorbic acid content in these studies. In our study, measurements were done by ascorbic acid test kits based on Boehringer enzymatic method. Falguera et al. (2011) reported the ascorbic acid of Starking type of apples as $788.20 \mathrm{mg} / \mathrm{L}$ measured

Table 1

Physicochemical properties of fresh CAJ and commercial pasteurized AJ.

\begin{tabular}{|c|c|c|c|c|c|c|c|c|c|}
\hline & \multirow[t]{2}{*}{$\mathrm{pH}$} & \multirow[t]{2}{*}{$\operatorname{Brix}\left({ }^{\circ}\right)$} & \multirow[t]{2}{*}{ TA (\%) } & \multirow[t]{2}{*}{ A.A (mg/L) } & \multirow[t]{2}{*}{ Absorption Coefficient $254 \mathrm{~nm}(1 / \mathrm{cm})$} & \multirow[t]{2}{*}{ Turbidity (NTU) } & \multicolumn{3}{|l|}{ Color } \\
\hline & & & & & & & $L^{*}$ & $a^{*}$ & $b^{*}$ \\
\hline CAJ & $3.92 \pm 0.01^{\mathrm{a}}$ & $13.63 \pm 0.04^{\mathrm{b}}$ & 0.33 & 2.22 & 28.53 & $1619 \pm 46^{b}$ & $25.43 \pm 0.09^{\mathrm{a}}$ & $1.60 \pm 0.12^{\mathrm{b}}$ & $6.71 \pm 0.06^{\mathrm{b}}$ \\
\hline AJ & $3.99 \pm 0.02^{\mathrm{b}}$ & $13.42 \pm 0.00^{\mathrm{a}}$ & 0.18 & - & 5.91 & $4.43 \pm 0^{\mathrm{a}}$ & $29.49 \pm 0.02^{\mathrm{b}}$ & $-0.28 \pm 0.01^{\mathrm{a}}$ & $6.12 \pm 0.00^{\mathrm{a}}$ \\
\hline
\end{tabular}

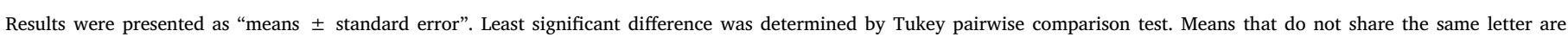
significantly different $(p<0.05)$.

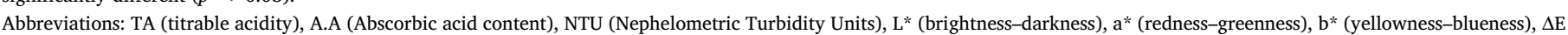
(total color difference). 


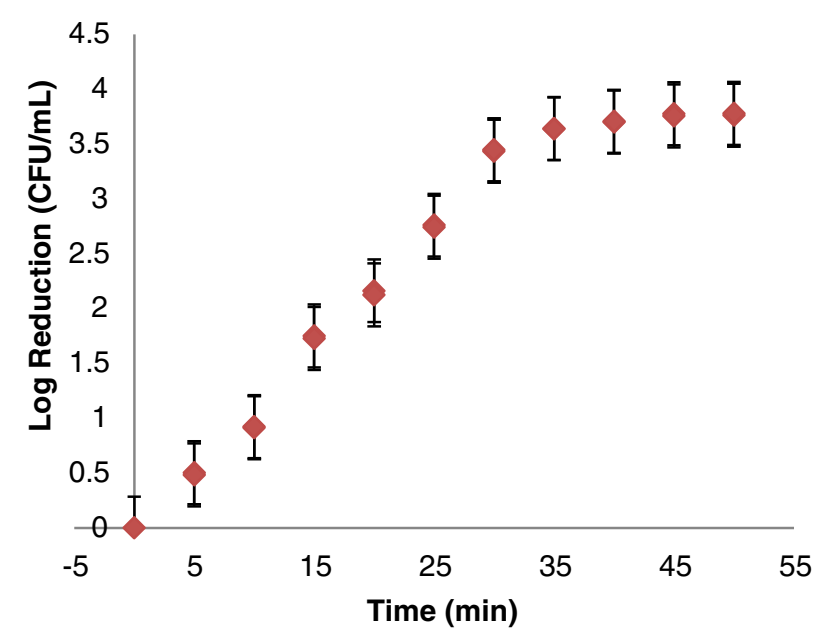

Fig. 3. The effect of 4 UV-LED lamps emitting light at $254 \mathrm{~nm}$ on the inactivation of E.coli K12 in CAJ.

by an iodine titration method. Besides Juarez-Enriquez et al. (2014) determined the ascorbic acid content as $211.75 \mathrm{mg} / \mathrm{kg}$ by using 2,6 dichloroindophenol method. On the other hand, the content of vitamin $\mathrm{C}$ in fruits and vegetables can be influenced by various factors such as genotypic differences, pre-harvest climatic conditions and cultural practices, maturity and harvesting methods, and postharvest handling procedures (Lee and Kader, 2000).

Absorbance is an important factor that affects the UV light intensity and its penetrating ability to liquid materials. Absorption coefficients of CAJ were calculated from the slope of absorbance values. In this study, the average absorption coefficients of CAJ and AJ were determined as $28.53_{(254 \mathrm{~nm})} ; 5.91_{(254 \mathrm{~nm})} \mathrm{cm}^{-1}$ which are in a good correlation with the ones obtained by Gayan et al. (2013) $\left(28.54 \mathrm{~cm}^{-1}\right)$.

Turbidity of the samples was changed greatly because of suspended particles. Although CAJ had many suspended solids in its composition and higher turbidity value as 1619 NTU, AJ was processed with a clarification step where suspended particles were removed. This step was resulted in less turbid juice as 4.43 NTU.

The color parameters $\left(\mathrm{L}^{*}, \mathrm{a}^{*}, \mathrm{~b}^{*}\right)$ of apple juice were determined $25.43 ; 1.60 ; 6.71$. The results were comparable with the ones obtained by Abid et al. (2013), Noci et al. (2008), Cominiti et al. (2012). The L*, $\mathrm{a}^{*}, \mathrm{~b} *$ values were in range of 19.27 and $25.40 ;-0.72$ and $1.33 ; 3.99$ and 6.75. The color parameters of juice samples were dissimilar although they were made of same kind of fruits. $L^{*}$ values of the juices indicated that CAJ $\left(L^{*}: 25.43\right)$ has a less light color than pasteurized AJ $\left(L^{*}:\right.$ 29.49). In contrast, $b^{*}$ value of the AJ as 6.12 was lower than CAJ due to carotenoid content in the juice composition. AJ had less carotenoid pigment comparing to CAJ due to carotenoid degradation caused by pasteurization process (Fratianni et al., 2010). Parameter a* that is responsible for redness of the juice was lower in the AJ. The loss of redness by a decrease of a* value was attributed to the breakdown of anthocyanin pigments during treatments.

\subsection{Thermal pasteurization}

Initial microbial load of fresh CAJ including total aerobic bacteria (TAC), yeast and mold counts (YMC) were 3.2 and $3.4 \log _{10} \mathrm{CFU} / \mathrm{mL}$. No coliform bacteria were detected in the fresh juice samples. Therefore, CAJ samples were pasteurized at different time temperature combinations. Heat treatments at $70{ }^{\circ} \mathrm{C}$ for $60 \mathrm{~s}$ were insufficient to reach $5 \log _{10}$ reduction of $E$. coli K12. The applications of heat treatment at $70{ }^{\circ} \mathrm{C}$ for longer than $60 \mathrm{~s}$, and the other heat treatments at $80{ }^{\circ} \mathrm{C}$ and $90{ }^{\circ} \mathrm{C}$ resulted in $>6 \log _{10} \mathrm{CFU} / \mathrm{mL}$ reduction. According to these results, the thermal treatment conditions, e.g. $70{ }^{\circ} \mathrm{C}-100 \mathrm{~s}, 70{ }^{\circ} \mathrm{C}$ $120 \mathrm{~s}$, and $80^{\circ} \mathrm{C}-15 \mathrm{~s}$ were found to be sufficient to obtain $5 \log _{10}$ reduction of E. coli $\mathrm{K} 12$ in apple juice. Moreover, at these process conditions, growth of TAC and YMC was not observed. Mazzotta (2001) calculated the industrial pasteurization conditions for fruit juices as $90{ }^{\circ} \mathrm{C}$ for $2 \mathrm{~s}$ and $84^{\circ} \mathrm{C}$ for $20 \mathrm{~s}$. However, the heat treatment at these high temperatures often causes losses of nutritional value and quality. Similarly, we observed that when the pasteurization temperature was higher than $80^{\circ} \mathrm{C}$, the color of juice samples was significantly affected (Fig. 5c). Therefore, mild heat pasteurization range in between 70 and $72{ }^{\circ} \mathrm{C}$ have begun to be applied in many studies to keep high quality in many types of fruit juices (Timmermans et al., 2011). The FDA has also recommended a minimum temperature $\left(71.1^{\circ} \mathrm{C}\right)$ and time $(3 \mathrm{~s})$ for pasteurization of food products having the $\mathrm{pH}$ range of 3.6 and 4.0 (FDA, 2004).

In conclusion, the thermal treatment carried out at $70{ }^{\circ} \mathrm{C}$ for $120 \mathrm{~s}$ was chosen as optimum condition to reach the $5 \log _{10}$ reduction in the target microorganism in CAJ. This temperature-time combination was also resulted in the minimum loss of physical, chemical and optical properties of the juice sample (Table 1).

\subsection{UV-LED processing}

\subsubsection{Determination of the exposure time}

In this study, the effective time, dose and wavelengths required for the inactivation of $E$. coli $\mathrm{K} 12$ in CAJ and AJ samples were determined. The effect of four UV-LEDs emitting light at $254 \mathrm{~nm}$ on the inactivation of $E$. coli $\mathrm{K} 12$ in CAJ is presented in Fig. 3. A linear decrease was observed in the $\log _{10}$ reduction of $E$. coli $\mathrm{K} 12$ up to $35 \mathrm{~min}$ of exposure time. The exposure time that was applied longer than $35 \mathrm{~min}$ did not change the inactivation efficiency of the lamps significantly. UV-LED irradiation at $254 \mathrm{~nm}$ applied for $40 \mathrm{~min}$ was resulted in $3.7 \log _{10} \mathrm{CFU} /$ $\mathrm{mL}$ reduction of $E$. coli K12 in CAJ (1909.50 NTU, $15.43_{254 \mathrm{~nm} \mathrm{~cm}}^{-1}$ ), while the UV-LED applied for $50 \mathrm{~min}$ provided $3.7 \log _{10} \mathrm{CFU} / \mathrm{mL}$ reduction. Although the inactivation efficiencies of $40 \mathrm{~min}$ and $50 \mathrm{~min}$ exposure times were not significantly different from each other $(p>0.05)$, the color of the juice sample was adversely affected in the second treatment. Thus, the maximum exposure time for UV-LED trials was determined as $40 \mathrm{~min}$. UV dose was estimated from the exposure time (40 min) and incident UV intensity (irradiance). Incident UV intensity (irradiance) emitted by each UV-LED lamp (in $\mathrm{mW} / \mathrm{cm}^{2}$ ) was measured by ferrioxalate actinometry method and shown in Table 2.

Ngadi et al. (2003) applied $300 \mathrm{~mJ} / \mathrm{cm}^{2} \mathrm{UV}$ dose at $0.32 \mathrm{~mW} / \mathrm{cm}^{2}$ incident UV intensity for $16 \mathrm{~min}$ in order to achieve $4.2 \log _{10}(\mathrm{CFU} / \mathrm{mL})$ reduction of E. coli O157:H7 (ATCC 35150) in apple juice $(0.02 \%$ transmittance) samples of $0.1 \mathrm{~cm}$ in depth. They irradiated the juice samples using a collimated beam apparatus consisted of a low-pressure mercury UV lamp with peak radiation in the $254 \mathrm{~nm}$ wavelength range. In another study, apple juice (absorption coefficient $5.81 \mathrm{~cm}^{-1}$ ) inoculated with E. coli K12 was treated with UV-C irradiation and $4.6 \log _{10} \mathrm{CFU} / \mathrm{mL}$ reduction was obtained (Caminiti et al., 2012). In our study, $707.19 \mathrm{~mJ} / \mathrm{cm}^{2} \mathrm{UV}$ dose at $0.295 \mathrm{~mW} / \mathrm{cm}^{2}$ average irradiance for $40 \mathrm{~min}$ was resulted in $3.70 \log _{10} \mathrm{CFU} / \mathrm{mL}$ reduction of $E$. coli $\mathrm{K} 12$ in CAJ of $0.15 \mathrm{~cm}$ in depth using four UV-LEDs emitting light at $254 \mathrm{~nm}$.

Table 2

Incident UV intensity (irradiance) and UV dose values.

\begin{tabular}{lll}
\hline $\begin{array}{l}\text { The wavelength of UV-LED lamp } \\
(\mathrm{nm})\end{array}$ & UV intensity $\left(\mathrm{mW} / \mathrm{cm}^{2}\right)$ & UV dose $\left(\mathrm{mJ} / \mathrm{cm}^{2}\right)$ \\
\hline 254 & $0.3 \pm 0.0$ & $707.2 \pm 143.5$ \\
280 & $0.3 \pm 0.0$ & $771.6 \pm 133.9$ \\
365 & $0.8 \pm 0.1$ & NA \\
405 & $0.4 \pm 0.1$ & NA \\
\hline
\end{tabular}




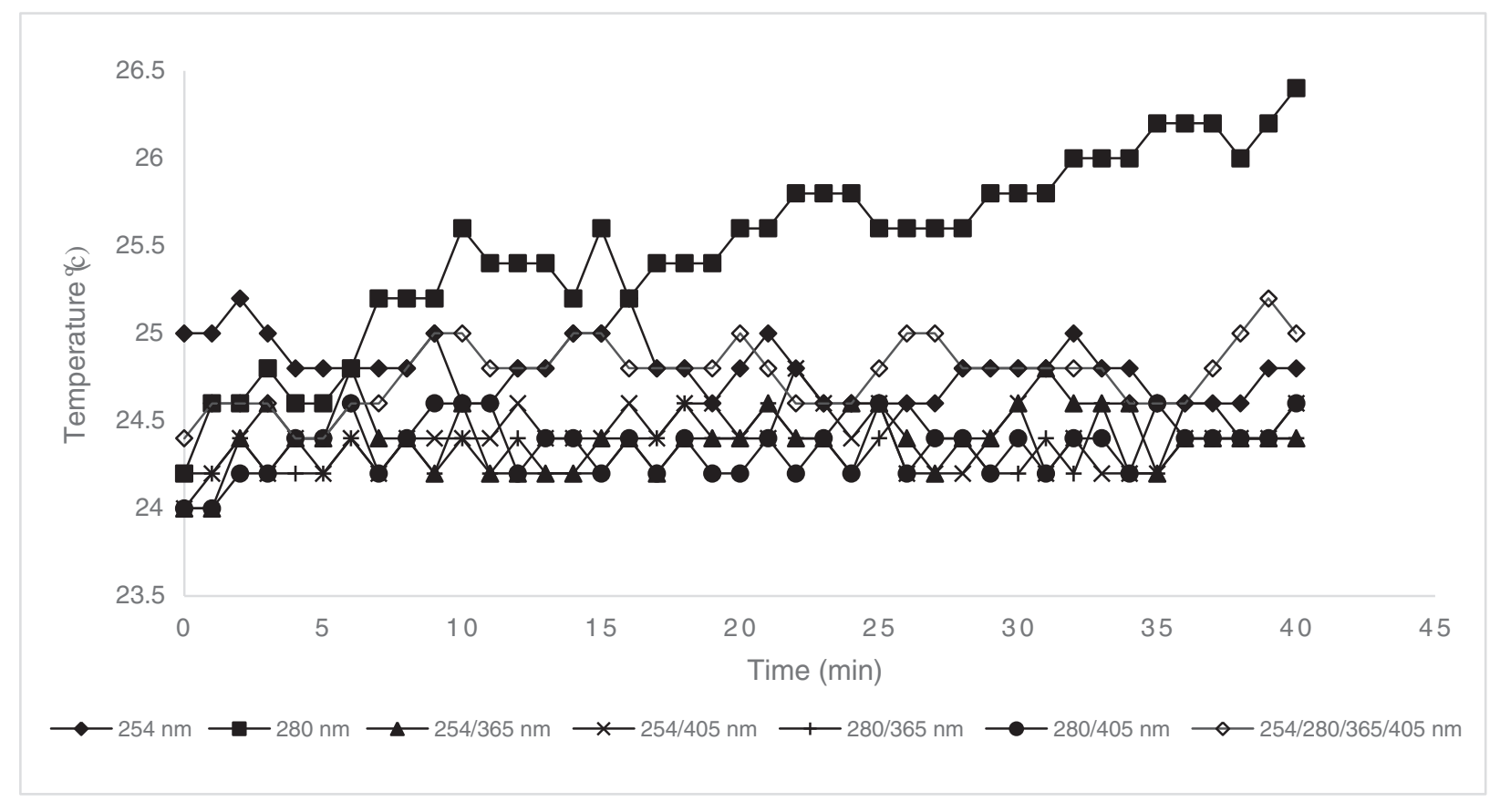

Fig. 4. Temperature flactuation during UV-LED treatments.

3.3.2. Microbial inactivation efficiency of UV-LEDs at different wavelengths

In this study, inactivation effects of different wavelengths of static bench top UV-LEDs system on E. coli K12 inoculated in CAJ and AJ were examined at $40 \mathrm{~min}$ exposure time. Temperatures of the CAJ samples were monitored and presented in Fig. 4. Temperature increase (max. $2.4{ }^{\circ} \mathrm{C}$ ) during the treatments was negligible. The logarithmic reduction values were demonstrated in Table 3 . The turbidity and absorption coefficients of CAJ used in this part of study were 908.5 NTU, $19.18_{254 \mathrm{~nm} \mathrm{~cm}} \mathrm{~cm}^{-1}, \quad 24.71_{280 \mathrm{~nm}} \mathrm{~cm}^{-1}, \quad 4.24_{365 \mathrm{~nm}} \mathrm{~cm}^{-1}$ and $2.60_{405 \mathrm{~nm}} \mathrm{~cm}^{-1}$, respectively. These values were different than those used in previous experiments. This was because apple juice samples used in the experiments were freshly prepared using apples purchased from the market at different time intervals. Thus, climate and seasonal changes cause a difference on the composition of apples and apple juice. Besides, the filtration of processes applied in obtaining cloudy juice may also have an effect on the physical properties of samples. For AJ, turbidity and absorption coefficient were measured as 4.43 NTU and $5.91 \mathrm{~cm}^{-1}$, respectively.

While the population of $E$. coli $\mathrm{K} 12$ in CAJ at $280 \mathrm{~nm}$ and 280-365 nm wavelength combination were maximum reduced by $2.0 \pm 0.1$ and $2.0 \pm 0.4 \log _{10} \mathrm{CFU} / \mathrm{mL}$ at a $40 \mathrm{~min}$ exposure time, in AJ the highest inactivation $\left(4.40 \log _{10} \mathrm{CFU} / \mathrm{mL}\right)$ obtained for $E$. coli K12 was achieved using four lamps emitting light at $280 \mathrm{~nm}$ for $40 \mathrm{~min}$ exposure time. For the same treatment time, the experiments using a combination of lamps emitting light at 280 and $365 \mathrm{~nm}$ (2lamp/2lamp) were resulted in $3.9 \pm 0.2 \log _{10} \mathrm{CFU} / \mathrm{mL}$ reductions. According to results it was clearly observed that UV-LED irradiation was more efficient on AJ than CAJ. The reason is because cloudy fluids have a low absorption of the UV due to the presence of color compounds, organic matter, and suspended solids; therefore, UV efficiency is lower than clear fluids (Koutchma, 2009).

Moreover, in two juices the germicidal effectiveness of $280 \mathrm{~nm}$ LEDs were higher than that of $254 \mathrm{~nm}$ LEDs. The inactivation activity achieved using a combined emission at $280-365 \mathrm{~nm}$ was very close to the results obtained at $280 \mathrm{~nm}(p>0.05)$. It is known that UV-A radiation is not directly absorbed by DNA. UV-A lights are able to induce DNA damage indirectly via the absorption of UV-A photons by photosensitizer cellular structures such as chromophores (Ravanat et al., 2001) which may result in formation of reactive oxygen species (ROS) such as singlet oxygen $\left({ }^{1} \mathrm{O}_{2}\right)$ and hydrogen peroxide $\left(\mathrm{H}_{2} \mathrm{O}_{2}\right)$. Later ROS can react with cellular components including DNA and proteins. Damage to DNA involves strand breaks, formation of 8-oxo-7, 8-dihydroguanine (8-oxo-dG), 2,6-diamino-4-hyroxy-5-formamido-pyrimidine of 2 -deoxygunosine and pyrimidine dimers and oxidation of pyrimidine bases (Hargreaves et al., 2007). Furthermore, it is known that UV light at UV-A wavelength $(320-400 \mathrm{~nm})$ inhibits the protein synthesis by damaging cell membranes and has better penetration property (Chatterley and Linden, 2010). On the other hand, UV-C light inactivates microorganisms by directly affecting the DNA of microorganisms causing the formation of cyclobutane thymine dimers, inactivating them without intermediate steps (Santos et al., 2013). DNA damage caused by UV-C irradiation can be repaired by photolyase

Table 3

Logarithmic reductions $\left(\log _{10} \mathrm{CFU} / \mathrm{mL}\right)$ of $E$. coli $\mathrm{K} 12$ in CAJ and AJ exposed to UV-LED irradiation at different wavelengths and exposure times.

\begin{tabular}{|c|c|c|c|c|c|c|c|c|}
\hline \multirow{3}{*}{$\begin{array}{l}\text { Juice Type } \\
\text { CAJ }\end{array}$} & \multirow{4}{*}{$\begin{array}{l}\text { Time (min) } \\
20 \\
40\end{array}$} & \multicolumn{7}{|c|}{ Wavelengths (nm) } \\
\hline & & 254 & 280 & $280-365$ & $280-405$ & $254-365$ & 254-405 & $254-280-365-405$ \\
\hline & & $1.10 \pm 0.01^{\mathrm{abA}}$ & $1.63 \pm 0.09^{\mathrm{cA}}$ & $0.94 \pm 0.21^{\mathrm{abA}}$ & $0.97 \pm 0.22^{\mathrm{abA}}$ & $0.60 \pm 0.09^{\mathrm{abA}}$ & $0.37 \pm 0.08^{\mathrm{aA}}$ & $1.05 \pm 0.32^{\mathrm{abA}}$ \\
\hline & & $1.64 \pm 0.05^{\mathrm{abB}}$ & $2.00 \pm 0.06^{\mathrm{bB}}$ & $1.98 \pm 0.39^{\mathrm{bA}}$ & $1.26 \pm 0.09^{\mathrm{aA}}$ & $1.38 \pm 0.11^{\mathrm{abB}}$ & $1.18 \pm 0.34^{\mathrm{aA}}$ & $1.72 \pm 0.33^{\mathrm{abA}}$ \\
\hline \multirow[t]{2}{*}{ AJ } & 20 & $3.58 \pm 0.04^{\mathrm{bA}}$ & $4.00 \pm 0.02^{\mathrm{cA}}$ & $3.54 \pm 0.08^{\mathrm{bA}}$ & $3.42 \pm 0.02^{\mathrm{bA}}$ & $1.79 \pm 0.06^{\mathrm{aA}}$ & $3.26 \pm 0.03^{\mathrm{bA}}$ & $3.35 \pm 0.26^{\mathrm{bA}}$ \\
\hline & 40 & $3.92 \pm 0.15^{\mathrm{bA}}$ & $4.40 \pm 0.14^{\mathrm{cA}}$ & $3.76 \pm 0.07^{\mathrm{bA}}$ & $3.58 \pm 0.03^{\mathrm{bB}}$ & $3.22 \pm 0.16^{\mathrm{aB}}$ & $3.77 \pm 0.08^{\mathrm{bB}}$ & $3.66 \pm 0.15^{\mathrm{bB}}$ \\
\hline
\end{tabular}

Results were presented as "means \pm standard error". Least significant difference was determined by Tukey pairwise comparison test.

${ }^{\mathrm{A}-\mathrm{B}}$ :Values within each exposure time followed by the same letter are not significantly different $(P>0.05)$.

${ }^{\mathrm{a}-\mathrm{c}}$ : Values within each wavelength and their combinations followed by the same letter are not significantly different $(P>0.05)$. 
enzymes, but UV-A rays damages these enzymes. The damage given to cell membranes by UV-A rays was irreversible. The combined emission at 280 and $365 \mathrm{~nm}$ increased the effectiveness of microbial inactivation caused by UV light (Chevremont et al., 2012b). Chevremont et al. (2012a) was reported that coupling of $280 / 365$ and $280 / 405 \mathrm{~nm}$ allowed obtaining a significant reduction on mesophilic bacteria in waste water than $254 \mathrm{~nm}$ which was the wavelength known to have a maximum germicidal effect. Additionally, it was indicated that UV-LEDs emitting light at $275 \mathrm{~nm}$ resulted in much higher microbial inactivation (Bowker et al., 2011). This is due to the fact that protein absorption spectrum may reaches the maximum near $280 \mathrm{~nm}$ and thus enzymes become more sensitive to inactivation by UV light emitted at these wavelengths (Chevremont et al., 2012a).

Low and medium pressure mercury-vapor lamps are used for conventional UV disinfection. Low pressure mercury lamps emit nearly monochromatic UV light at a wavelength of $254 \mathrm{~nm}$ which coincides very well with the peaks of the germicidal effectiveness curve (i.e. the effectiveness for UV absorption by DNA). UV LEDs offer the possibility to use the optimum wavelength for disinfection instead of the $254 \mathrm{~nm}$ emitted by low pressure mercury lamps. However, there was no study in the literature related to the assessment of the effect of UV-LEDs on the inactivation of microorganisms in fruit juices. So, it was hard to compare our results with others.

\subsection{The effect of UV-LED irradiation on PPO enzyme activity}

Table 4 shows the changes in activity of PPO in CAJ exposed to UV light at $24{ }^{\circ} \mathrm{C}$ and thermally pasteurized CAJ. UV-LED treatment was able to reduce the activity of PPO. The highest inactivations with $67.42 \%$ and $65.62 \%$ were achieved in the process when the combinations of emission at $280-365 \mathrm{~nm}$ and $280-405 \mathrm{~nm}$ were used. The activity of PPO in CAJ subjected to UV light at 254 and $280 \mathrm{~nm}$ wavelength was reduced to $70.43 \%$ and $56.35 \%$, respectively. It was clearly observed that UV-LED irradiation coupling UV-A and UV-C rays showed a better inactivation efficiency on PPO enzyme than the one used only UV-C rays. It was reported that the enzyme inactivation using UV-C light depends on the juice matrix and its composition (Müller et al., 2014). High absorption coefficient of cloudy apple juice implies that the penetration depth of the UV-C light in juice is very small, thus the enzyme inactivation was low. Tran and Farid (2004) and Noci et al. (2008) found that UV-C light treatment has no noticeable effect on the enzymes such as pectinmethylesterase (PME), polyphenoloxidase (PPO) and peroxidase (POD). Muller et al. (2014) was investigated the effect of UV-C and UV-B irradiation on PPO activation in apple $\left(52.4 \mathrm{~cm}^{-1}\right)$

Table 4

Residual Activity (\%) of PPO in CAJ treated with thermal pasteurization and UV-LED irradiation.

\begin{tabular}{lll}
\hline & & \\
\hline \multirow{2}{*}{ Thermally Pasteurized CAJ } & $70{ }^{\circ} \mathrm{C} 100 \mathrm{~s}$ & $25.76 \pm 1.38^{\mathrm{B}}$ \\
& $70^{\circ} \mathrm{C} 120 \mathrm{~s}$ & $22.34 \pm 0.06^{\mathrm{A}}$ \\
& $85^{\circ} \mathrm{C} 15 \mathrm{~s}$ & $27.37 \pm 0.17^{\mathrm{B}}$ \\
UV-LED Irradiated CAJ (40 min) & $254 \mathrm{~nm}$ & $70.43 \pm 3.38^{\mathrm{d}}$ \\
& $280 \mathrm{~nm}$ & $56.35 \pm 5.38^{\mathrm{c}}$ \\
& $254 / 365 \mathrm{~nm}$ & $50.01 \pm 1.62^{\mathrm{b}}$ \\
& $254 / 405 \mathrm{~nm}$ & $47.76 \pm 1.79^{\mathrm{b}}$ \\
& $280 / 365 \mathrm{~nm}$ & $32.58 \pm 0.77^{\mathrm{a}}$ \\
& $280 / 405 \mathrm{~nm}$ & $34.38 \pm 1.61^{\mathrm{a}}$ \\
& $254 / 280 / 365 /$ & $42.87 \pm 1.45^{\mathrm{b}}$ \\
& $405 \mathrm{~nm}$ & \\
\hline
\end{tabular}

Results were presented as "means \pm standard error". Least significant difference was determined by Tukey pairwise comparison test.

A-B: Values within each thermally pasteurized CAJ followed by the same letter are not significantly different $(P>0.05)$.

${ }^{\mathrm{a}-\mathrm{d}}$ : Values within each UV-LED Irradiated CAJ $(40 \mathrm{~min})$ followed by the same letter are not significantly different $(P>0.05)$. and grape $\left(43.5 \mathrm{~cm}^{-1}\right)$ juice by means of UV-C processing unit equipped with a Dean flow reactor. Even though, they did not observe a significant effect on PPO enzyme activity, a reduction of PPO activity of $>20 \%$ and $40 \%$ was reported in apple and grape juices subjected to UV-B (290-315 nm) irradiation, at UV dose of $100.48 \mathrm{~kJ} \mathrm{~L}^{-1}$. Falguera et al. (2011) irradiated fresh apple juices for $120 \mathrm{~min}$ using a high pressure mercury UV lamp ( $400 \mathrm{~W}$, emitting light between 250 and $740 \mathrm{~nm}$ ), They were able to inactivate Polyphenol oxidase in $100 \mathrm{~min}$, while peroxidase was completely destroyed in only $15 \mathrm{~min}$.

\subsection{Effect of UV-LED irradiation on color}

The color of a fruit juice is an important visual criterion that can be directly influenced by the presence of various colored pigments, enzymatic activities as well as the microbial contamination (Bhat, 2016). The effect of UV-LED irradiation at different wavelengths and thermal pasteurization on color of CAJ was investigated in this study. As presented in Fig. 5, significant differences in the colorimetric parameters and the total color difference value $(\Delta \mathrm{E})$ was recorded in UV-LED treated and thermally pasteurized samples.

$L^{*}$ value was the only parameter remained almost constant after exposure to UV-LED irradiation. The minimum changes in $L^{*}$ value was observed at the processing condition when UV-LED irradiation were coupled at $280 / 365 \mathrm{~nm}$ wavelength. On the other hand, thermal pasteurization at $70{ }^{\circ} \mathrm{C}$ for $100 \mathrm{~s}$ and $80^{\circ} \mathrm{C}$ for $15 \mathrm{~s}$ adversely affected brightness of CAJ due to the partial precipitation of suspended particles. Lee and Coates (1999) reported that precipitation of insoluble particles from cloudy apple juice suspension cause the increment of lightness after pasteurization.

Parameters of $\mathrm{a}^{*}$ and $\mathrm{b} *$ were highly influenced after UV-LED irradiation and thermal treatment (Fig. 5b,c). The most noticeable change in $\mathrm{a}^{*}$ values was observed in CAJ samples exposed to UV-LED irradiation at $280 / 365 \mathrm{~nm}$. This was probably due to photo degradation of anthocyanins due to the discoloration effects of UV light on pigments (Guerrero-Beltra'n et al., 2009). In contrast, at this condition, the change in $b^{*}$ value was lower compared to the ones treated with any other wavelengths and their combinations.

The lowest color difference $(\Delta \mathrm{E})$ was estimated for samples subjected to UV-LED irradiation at $280 / 365 \mathrm{~nm}$ and determined as 'noticeable' (1.5-3.0) (Cserhalmi et al., 2006). This finding was well correlated with the residual PPO enzyme activity and ascorbic acid degradation in CAJ samples. Residual activity of PPO in CAJ was the lowest $(32.58 \%)$ when treated with UV-LED in combination of UV-C $(280 \mathrm{~nm})$ and UV-A $(365 \mathrm{~nm})$ rays (Table 4). Similarly, Juarez-Enriquez et al. (2016) achieved complete PPO enzyme inactivation in apple juice after $180 \mathrm{~min}$ of ultraviolet irradiation but observed significant color change expressed as hue. They referred the variation in hue to double bounds disruption and oxidation reactions during UV treatment. Additionally, it was observed that the ascorbic acid was completely diminished after thermal and UV-LED processing. Tikekar et al. (2011) showed that ascorbic acid degradation in foods accelerated by exposure to visible light and polychromatic UV radiation supporting the results of this study. They suggested that UV-induced degradation of ascorbic acids proceeded by a similar mechanism as that for the general metalcatalyzed oxidation pathway.

On the other hand, the recorded results in this study indicated that juice samples exposed to thermal treatment exhibited 'well visible' (3.0-6.0) and 'great' (6.0-12.0) difference in color. High $\Delta \mathrm{E}$ values can be attributed to the destruction/alterations in the colored pigmented compounds as well as to the enhancement in browning degree (nonenzymatic browning) after thermal treatments (Bhat, 2016).

\section{Conclusion}

In this study, the efficiency of four different UV-LEDs emitting light at different wavelengths on the inactivation of E. coli K12 and PPO 


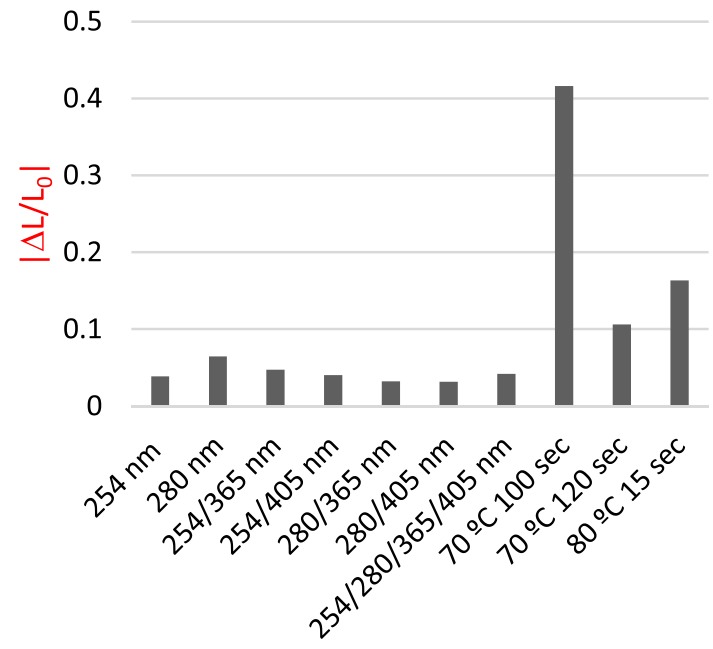

Treatments

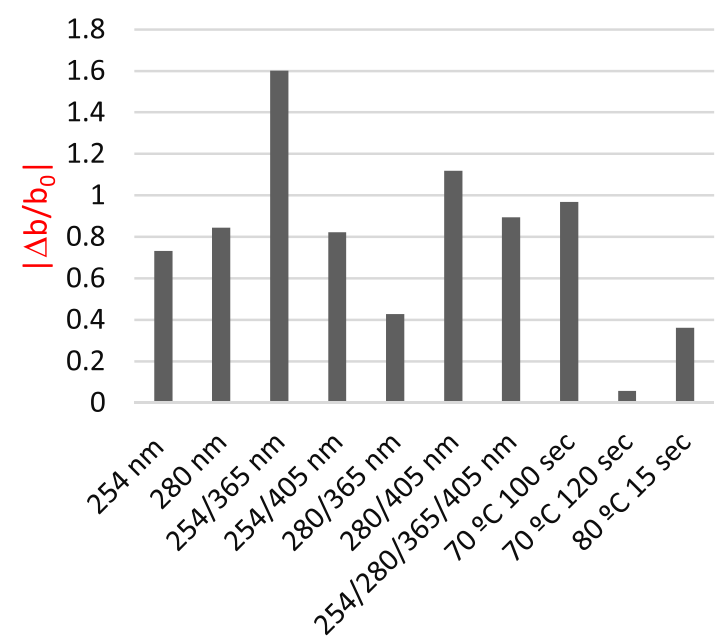

Treatments
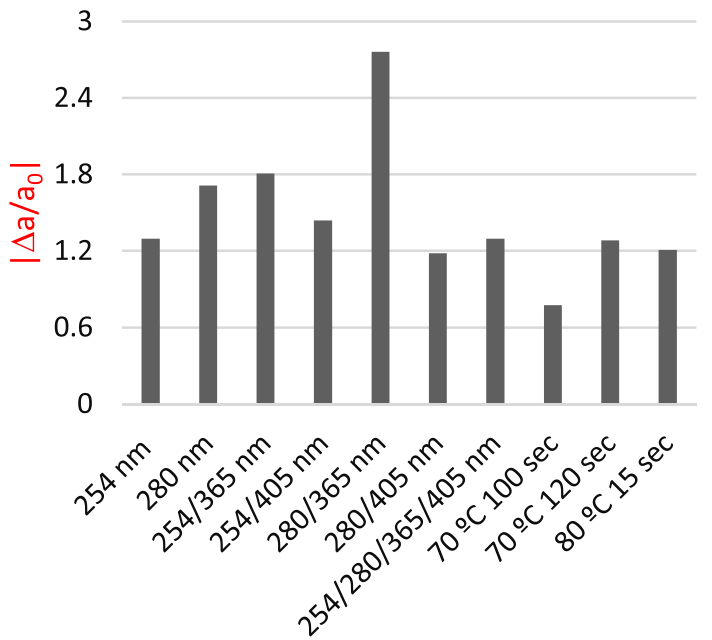

Treatments
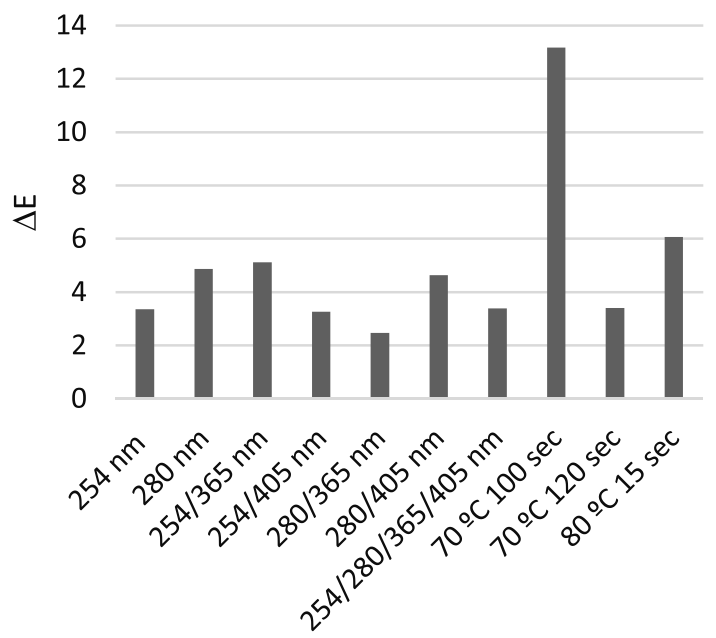

Treatments

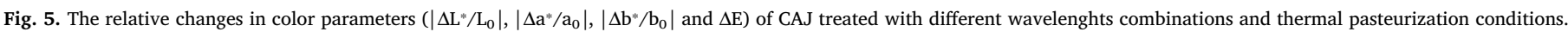

enzyme in cloudy and clear apple juice was investigated. The results showed that a batch reactor equipped with 4 UV-LEDs did not provide $5 \log _{10}$ reduction on target microorganism (E. coli K12) in CAJ. However, coupled wavelength $280 / 365 \mathrm{~nm}$ was more influential on inactivation of $E$. coli $\mathrm{K} 12$ than when LEDs emits $254 \mathrm{~nm}$ was used individually in spite of its maximum germicidal effect. Reduction of PPO activity emitted UV-LED treatment cannot be still as effective as heat treatment. However, compared with UV-C irradiation, it was found that PPO enzyme inactivation efficiency of UV-LEDs emitted at UV-A and UV-C range were higher than traditional low pressure mercury lamps. Similarly, combination of UV-A and UV-C provided a better preservation of color of CAJ compared to UV-C irradiation and thermal treatment. There are limited numbers of studies in the literature related to use of UV-LEDs for fruit juice processing. Therefore, this study holds significant potential for being one of the first studies in this field. This preliminary study point out that new UV light disinfection equipment, effective on both bacteria and enzyme, of low energy consumption can be designed in various shapes and sizes without using harmful (e.g. mercury) substances. If UV-LEDs can be used instead of conventional low-pressure mercury lamps, it will be possible to miniaturize the devices used for disinfection purposes and hold a potential to become an economic processing method for juices.

\section{Acknowledgement}

This study was supported by the Scientific and Technical Research Council of Turkey (TUBITAK), Project No: TOVAG-113 O 200.

\section{References}

Abid, M., Jabbar, S., Wu, T., Hashim, M., Hu, B., Lei, S., Zhang, X., Zeng, X., 2013. Effect of ultrasound on different quality of apple juice. Ultrason. Sonochem. 20, 1182-1187. Aguilar-Rosas, S.F., Ballinas-Casarrubias, M.L., Nevarez-Moorillon, G.V., Martin-Belloso, O., Ortega-Rivas, E., 2007. Thermal and pulsed electric fields pasteurization of apple juice: effects on physicochemical properties and flavour compounds. J. Food Eng. 83, $41-46$.

Aoyagi, Y., Takeuchi, M., Yoshida, K., Kurouchi, M., Yasui, N., Kamiko, N., Araki, T. Nanishi, Y., 2011. Inactivation of bacterial viruses in water using deep ultraviolet semiconductor light-emitting diode. J. Environ. Eng. 137, 1215-1218.

Basaran-Akgul, N., Churey, J.J., Basaran, P., Worobo, R.W., 2009. Inactivation of different strains of Escherichia coli O157:H7 in various apple ciders treated with dimethyl dicarbonate (DMDC) and sulfur dioxide $\left(\mathrm{SO}_{2}\right)$ as an alternative method. Food Microbiol. 26, 8-15.

Begum, M., Hocking-Ailsa, D., Miskelly, D., 2009. Inactivation of food spoilage fungi by ultraviolet (UVC) irradiation. Int. J. Food Microbiol. 129, 74-77.

Bhat, R., 2016. Impact of ultraviolet radiation treatments on the quality of freshly prepared tomato (Solanum lycopersicum) juice. Food Chem. 213, 635-640.

Bi, X., Liu, F., Rao, L., Li, J., Liu, B., Liao, X., Wu, J., 2013. Effects of electric field strength and pulse rise time on physicochemical and sensory properties of apple juice by 
pulsed electric field. Innovative Food Sci. Emerg. Technol. 17, 85-92.

Bintsis, T., Tzanetaki, E.L., Robinson, R.K., 2000. Existing and potential applications of ultraviolet light in the food industry - a critical review. J. Sci. Food Agric. 80, 637-645.

Bohrerova, Z., Shemer, H., Lantis, R., Impellitteri, C.A., Linden, K.G., 2008. Comparative disinfection efficiency of pulsed and continuous-wave UV irradiation technologies. Water Res. 42, 2975-2982.

Bolton, J.R., Linden, K.G., Asce, M., 2003. Standardization of methods for fluence UV dose determination in bench-scale UV experiments. J. Environ. Eng. 129 (3), 209-215.

Borenstein, A.R., Dai, Q., Wu, Y., Jackson, J.C., Larson, E.B., 2005. Consumption of fruit and vegetable juices predicts a reduced risk of AD. The Kame Project. In: Presented at Alzeheimer's Association International Conference on the Prevention of Dementia, June 18-21, in Washington DC, USA.

Bowker, C., Sain, A., Shatalov, M., Ducoste, J., 2011. Microbial UV Fluence-response assessment using a novel UV-LED collimated beam system. Water Res. 45, 2011-2019.

Braidot, E., Petrussa, E., Peresson, C., Patui, S., Bertolini, A., Tubaro, F., W“ahlby, U., Coan, M., Vianello, A., Zancani, M., 2014. Low-intensity light cycles improve the quality of lamb's lettuce (Valerianella olitoria [L.] Pollich) during storage at low temperature. Postharvest Biol. Technol. 90, 15-23.

Caminiti, I.M., Palgan, I., Muñoz, A., Noci, F., Whyte, P., Morgan, D.J., Cronin, D.A. Lyng, J.G., 2012. The effect of ultraviolet light on microbial inactivation and quality attributes of apple juice. Food Bioprocess Technol. 5, 680-686.

Chatterley, C., Linden, K., 2010. Demonstration and evaluation of germicidal UV-LEDs for point-of-use water disinfection. J. Water Health 8 (3), 479-486.

Chevremont, A.C., Farnet, A.M., Coulomb, B., Boudenne, J.L., 2012a. Effect of coupled UV-A and UV-C LEDs on both microbiological and chemical pollution of urban wastewaters. Sci. Total Environ. 426, 304-310.

Chevremont, A.C., Farnet, A.M., Sergent, M., Coulomb, B., Boudenne, J.L., 2012b. Multivariate optimization of fecal bioindicator inactivation by coupling UV-A and UV-C LEDs. Desalination 285, 219-225.

Choi, L.H., Nielsen, S.S., 2004. The effects of thermal and nonthermal processing methods on apple cider quality and consumer acceptability. J. Food Qual. 28, 13-29.

Cook, K.A., Dobbs, T.E., Hlady, W.G., Wells, J.G., Barrett, T.J., Puhr, N.D., Lancette, G.A., Bodager, D.W., Toth, B.L., Genese, C.A., Highsmith, A.K., Pilot, K.E., Finelli, L., Swerdlow, D.L., 1998. Outbreak of salmonella serotype Hartford infections associated with unpasteurized orange juice. JAMA 280 (17), 1504-1509.

Crawford, M.H., Banas, M.A., Ross, M.P., Ruby, D.S., Nelson, J.S., Boucher, R., Allerman, A.A., 2005. Final LDRD report: ultraviolet water purification systems for rural environments and mobile applications. In: Sandia Report, pp. 1-37 (SAND7245).

Cserhalmi, Z.S., Sass-Kiss, A., Tóth-Markus, M., Lechner, N., 2006. Study of pulsed electric field citrus juices. Innovative Food Sci. Emerg. Technol. 7, 49-54.

Danielczuk, J., Pietrzykowski, R., Zielinski, W., 2004. Comparative study of the enzymatic method for determination of Vitamin C with routine methods according to ISO. Pol. J. Food Nutr. Sci. 13 (54), 41-46.

Dhakal, R., Baek, K.H., 2014. Short period irradiation of single blue wavelength ligh extends the storage period of mature green tomatoes. Postharvest Biol. Technol. 90, $73-80$

D'Souza, C., Yuk, H.G., Khoo, G.H., Zhou, W., 2015. Application of light-emitting diodes in food production postharvest preservation, and microbiological food safety. Compr. Rev. Food Sci. Food Saf. 0 (2015), 1-21.

Edelahi, M.C., 2004. Contribution to the study of the in situ degradation of pesticides by advanced oxidation processes involving the use of iron. In: Application to the Phenylureas Herbicides PhD Thesis. Université de Marne-La-Vallée.

Falguera, V., Pagan, J., Garza, S., Garvin, A., Ibarz, A., 2011. Ultraviolet processing of liquid food: a review part 2: effects on microorganisms and on food components and properties. Food Res. Int. 44, 1580-1588.

Falguera, V., Pagan, J., Ibarz, A., 2012. Effect of UV irradiation on enzymatic activities and physicochemical properties of apple juices from different varieties. LWT-Food Sci. Technol. 44, 115-119.

Foley, D.M., Pickett, K., Varon, J., Lee, J., Min, D.B., Caporaso, F., Prakash, A., 2002 Pasteurization of fresh orange juice using gamma irradiation: microbiological, flavor, and sensory analyses. J. Food Sci. 67, 1495-1501.

FDA, 2004. Food and Drug Administration. Guidance for industry: Juice HACCP hazards and controls guidance Final Guidance, March 3, 2004. In: U.S. Department of Healthand Human Services, Center for Food Safety and Applied Nutrition (CFSAN), 1st ed. . http://www.fda.gov/Food/GuidanceComplianceRegulatoryInformation/ GuidanceDocuments/Juice/ucm072557.htm.

Fratianni, A., Cinquanta, L., Panfili, G., 2010. Degradation of carotenoids in orange juice during microwave heating. LWT Food Sci. Technol. 43, 867-871.

Gayan, E., Serrano, M.J., Monfort, S., Alvarez, I., Condon, S., 2013. Pasteurization of apple juice contaminated with Escherichia coli by a combined UV-mild temperature. Food Bioprocess Technol. 6, 3006-3016.

Goldstein, S., Rabani, J., 2008. The ferrioxalate and iodide-iodate actinometers in the UV region. J. Photochem. Photobiol. A Chem. 193, 50-55.

Guerrero-Beltra'n, J.A., Velti-Chanes, J., Barbosa-Canovas, G.V., 2009. Ultraviolet-C light processing of grape, cranberry and grapefruit juices to inactivate Saccharomyces cerevisiae. J. Food Process Eng. 32, 916-932.

Hakgüder, B., 2009. UV Disinfection of Some of the Fruit Juices. MS Thesis. Izmir Institute of Technology.

Hamamoto, A., Mori, M., Takahashi, A., Nakano, M., Wakikawa, N., Akutagawa, M., Ikehara, T., Nakaya, Y., Kinouchi, Y., 2007. New water disinfection system using UVA light-emitting diodes. J. Appl. Microbiol. 103, 2291-2298.

Hargreaves, A., Taiwo, F.A., Duggan, O., Kirk, S.H., Ahmad, S.I., 2007. Near-ultraviolet photolysis of $\beta$-phenylpyruvic acid generates free radicals and results in DNA damage. J. Photochem. Photobiol. B Biol. 89, 110-116.

Jankowski, J.J., Kieber, D.J., Mopper, K., 1999. Nitrate and nitrite ultraviolet actinometers. Photochem. Photobiol. 70 (3), 319-328.

Juarez-Enriquez, E., Sameron-Ochoa, L., Gutierrez-Mendez, N., Ramaswamy, H.S. Ortega-Rivas, E., 2014. Shelf life studies on apple juice pasteurization by ultrahigh hydrostatic pressure. LWT- Food Sci. Technol. 62, 915-919.

Juarez-Enriquez, E., Salmerón, I., Gutierrez-Mendez, N., Ortega-Rivas, E., 2016. Ultraviolet irradiation effect on apple juice bioactive compounds during shelf storage. Foods 5, 10 .

Keevil, J.G., Osman, H.E., Reed, J.D., Folts, J.D., 2000. Grape juice, but not orange juice or grapefruit juice, inhibits human platelet aggregation. J. Nutr. 130, 53-56.

Koutchma, T., 2009. Advances in ultraviolet light technology for non-thermal processing of liquid foods. Food Bioprocess Technol. 2, 138-155.

Koutchma, T., Keller, S., Chirtel, S., Parisi, B., 2004. Ultraviolet disinfection of juice products in laminar and turbulent flow reactors. Innov. Food Sci. Eng. Technol. 5 , 179-189.

Kuhn, H.J., Braslavsky, S.E., Schmidt, R., 2004. Chemical actinometry. Pure Appl. Chem. $76,2105-2146$.

Lee, H.S., Coates, G.A., 1999. Thermal pasteurization effects on color of red grapefruit juices. J. Food Sci. 64 (4), 663-666.

Lee, S.K., Kader, A.A., 2000. Preharvest and postharvest factors influencing vitamin C content of horticultural crops. Postharvest Biol. Technol. 20 (3), 207-220.

Li, J., Hirota, K., Yumoto, H., Matsuo, T., Miyake, Y., Ichikawa, T., 2010. Enhanced germicidal effects of pulsed UV-LED irradiation on biofilms. J. Appl. Microbiol. 109, 2183-2190.

Lui, G.Y., Roser, D., Corkish, R., Ashbolt, N., Jagals, P., Stuetz, R., 2014. Photovoltaic powered ultraviolet and visible light-emitting diodes for sustainable point-of-use disinfection of drinking waters. Sci. Total Environ. 493, 185-196.

Ma, G., Zhang, L., Setiawan, C.K., Yamawaki, K., Asai, T., Nishikawa, F., Maezawa, S., Sato, H., Kanemitsu, N., Kato, M., 2014. Effect of red and blue LED light irradiation on ascorbate content and expression of genes related to ascorbate metabolism in postharvest broccoli. Postharvest Biol. Technol. 94, 97-103.

Mazzotta, A.S., 2001. Thermal inactivation of stationary-phase and acid-adapted Escherichia coli 0157:H7. Salmonella and Listeria monocytogenes in fruit juices. J. Food Prot. 64, 315-320.

Mori, M., Hamamoto, A., Takahashi, A., Nakano, M., Wakikawa, N., Tachibana, S., Ikehara, T., Nakaya, Y., Akutagawa, M., Kinouchi, Y., 2007. Development of a new water sterilization device with a 365 nm UV-LED. Med. Biol. Eng. Comput. 45, $1237-1241$.

Müller, A., Noack, L., Greiner, R., Stahl, M.R., Posten, C., 2014. Effect of UV-C and UV-B treatment on polyphenol oxidase activity and shelf life of apple and grape juice. Innov. Food Sci. Eng. Technol. 26, 498-504.

Murakami, E.G., Jackson, L., Madsen, K., Schickedanz, B., 2006. Factors affecting the ultraviolet inactivation of Escherichia coli K12 in apple juice and a model system. J. Food Process Eng. 29, 53-71.

Ngadi, M., Smith, J.P., Cayouette, B., 2003. Kinetics of ultraviolet light inactivation of Escherichia coli O157:H7 in liquid foods. J. Sci. Food Agric. 83, 1551-1555.

Nigro, F., Ippolito, A., Lima, G., 1998. Use of UV-C to reduce storage rot of table grape. Postharvest Biol. Technol. 13, 171-181.

Noci, F., Riener, J., Walkling-Ribeiro, M., Cronin, D.A., Morgan, D.J., Lyng, J.G., 2008. Ultraviolet irradiation and pulsed electric fields. (PEF) in a hurdle strategy for the preservation of fresh apple jucie. J. Food Eng. 85, 141-146.

Oguma, K., Katayama, H., Ohgaki, S., 2002. Photoreactivation of E. coli after low or medium-pressure UV disinfection determined by an endonuclease sensitive site assay. Appl. Environ. Microbiol. 68, 6029-6035.

Pala, C.U., Toklucu, A.K., 2013. Microbial, physicochemical and sensory properties of UV$\mathrm{C}$ processed orange juice and its microbial stability during refrigerated storage. LWT Food Sci. Technol. 50, 426-431.

Pan, J., Vicente, A.R., Martinez, G.A., Chaves, A.R., Civello, P.M., 2004. Combined use of UV-C radiation and heat treatment to improve postharvest life of strawberry fruit. J. Sci. Food Agric. 84, 1831-1838.

Ravanat, J.-L., Douki, Thierry, Cadet, J., 2001. Direct and indirect effects on UV radiation on DNA and its components. J. Photochem. Photobiol., B 63, 88-102.

Santos, L.A., Oliveira, V., Baptista, I., Henriques, I., Gomes, N.C.M., Almeida, A., Correia, A., Cunha, A., 2013. Wavelength dependence of biological damage induced by UV radiation on bacteria. Arch. Microbiol. 195, 63-74.

Shi, L., Cao, S., Chen, W., Yang, Z., 2014. Blue light induced anthocyanin accumulation and expression of associated genes in Chinese bayberry fruit. Sci. Hortic. 179, 98-102.

Stein, J.H., Keevil, J.G., Wiebe, D.A., Aeschlimann, S., Folts, J.D., 1999. Purple grape juice improves endothelial function and reduces the susceptibility of LDL cholesterol to oxidation in patients with coronary artery disease. J. Am. Heart Assoc. 100, 1050-1055.

Tahiri, I., Makhlouf, J., Paquin, P., Fliss, I., 2006. Inactivation of food spoilage bacteria and Escherichia coli O157:H7 in phosphate buffer and orange juice using dynamic high pressure. Food Res. Int. 39, 98-105.

Tandon, K., Worobo, R.W., Churey, J.J., Padilla-Zakour, O.I., 2003. Storage quality of pasteurized and UV treated apple cider. J. Food Process. Preserv. 27, 21-35.

Tikekar, R.V., Anantheswaran, R.C., Elias, R.J., LaBorde, L.F., 2011. Ultraviolet-induced oxidation of ascorbic acid in a model juice system: identification of degradation products. J. Agric. Food Chem. 59, 8244-8248.

Timmermans, R.A.H., Mastwijk, H.C., Knol, J.J., Quataert, M.C.J., Vervoort, L., Van der Plancken, I., Hendrickx, M.E., Matser, A.M., 2011. Comparing equivalent thermal, high pressure and pulsed electric field processes for mild pasteurization of orange juice; part 1: impact on overall quality attributes. Innovative Food Sci. Emerg. Technol. 12, 235-243. 
Tran, M.T.T., Farid, M., 2004. Ultraviolet treatment of orange juice. Innovative Food Sci. Emerg. Technol. 5, 495-502.

Unluturk, S., Atılgan, M.R., Baysal, H.A., Unluturk, M.S., 2010. Modeling inactivation kinetics of liquid egg white exposed to UV-C irradiation. Int. J. Food Microbiol. 142, 341-347.

Würtele, M.A., Kolbe, T., Lipsz, M., Külberg, A., Weyers, M., Kneissl, M., Jekel, M., 2011. Application of GaN-based ultraviolet-C light emitting diodes (UV LEDs) for water disinfection. Water Res. 45, 1481-1489.

Xu, F., Cao, S., Shi, L., Chen, W., Su, X., Yang, Z., 2014a. Blue light irradiation affects anthocyanin content and enzyme activities involved in postharvest strawberry fruit. J. Agric. Food Chem. 62, 4778-4783.

Xu, F., Shi, L., Chen, W., Cao, S., Su, X., Yang, Z., 2014b. Effect of blue light treatment on fruit quality, antioxidant enzymes and radical-scavenging activity in strawberry fruit. Sci. Hortic. 175, 181-187. 